\title{
6
}

\section{Water-Energy-Mining and Sustainable Consumption: Views of South American Strategic Actors}

\author{
Cristián Parker, Gloria Baigorrotegui and Fernando Estenssoro
}

\section{Introduction}

Mining activity has undeniable environmental impacts due to the nature of its operations, processing plants and foundries. Mining companies proclaim their environmental responsibility by implementing policies that limit environmental risk and impact, while also applying new technologies and production processes that are more respectful of the environment. The degree of efficacy of these sustainability measures and the degree to which companies voluntarily ensure environmental care cannot belie the fact that - no matter what - mining activity has and will always have environmental impacts. There are two major points of view about the subject, according to Whitmore (2006). On the one hand, there are the views of companies - that is to say, the actors who control the mining bulldozers and claim to ensure that everything goes well and that mining is, or can be, sustainable. On the other hand, there are the views of those who are affected by mining activity, such as the communities, peasants and indigenous peoples who are displaced without proper consultation, who suffer illnesses, and whose lifestyles, health and environment are impacted.

This chapter will not address the mining problem from the conventional perspective of whether or not mining is sustainable. The majority of the socioenvironmental conflicts that arise around mining are focused on this problem. ${ }^{1}$ We refer to the fact that mining consumes large quantities of water and energy and is one of the most widespread productive activities. As AngloGold Ashanti's sustainability report declares, ${ }^{2}$ mining activity has a direct impact on the environment 
because it requires access to land, water and energy, scarce resources that should be shared with the communities in which it operates. Mining processes also require "considerable amounts of water" and "significant quantities of energy" in order to function.

The sustainable consumption of strategic natural resources such as water and energy in South American mining is a key theme that challenges environmental governance, but it is rarely studied by the social sciences. This is especially true in the case of the mining sector. Since the 2000s, the mining boom has resulted in expanded investment in all of the countries in the region, in many cases generating socioenvironmental conflicts (Svampa and Antonelli, 2009; Teijlingen, 2012). And this trend is likely to continue in the coming years. ${ }^{3}$

The research that we present here looks into the different social representations $s^{4}$ of strategic actors with respect to the sustainable consumption $^{5}$ of energy and water in the mining sector. These social representations of environmental issues are fundamental to understanding the social and institutional practices aimed towards sustainable consumption and environmental governance (Hajer and Versteeg, 2005). With strategic actors we refer to members of elites who have the capacity for long-term influence, and who may come from the private sector or the public sector as well as from organized civil society. We include strategic actors who are linked to a few paradigmatic mining cases in four South American countries: Argentina, Chile, Colombia and Ecuador.

\section{Problem under study: The water-energy-mining complex}

The main questions of the study are related to the configuration of the social representations - of an institutional nature and pertaining to strategic actors - of water and energy, and actors' views of nature and development. In order to understand the viability of forms of governance for the sustainable and equitable consumption of water and energy in the cases studied, we want to see which different representational models can be observed and on which points they coincide. As a result of climate change (PNUMA, SEMARNAT, 2006), nature - and in particular water and energy - is increasingly understood to be of strategic significance (Bruzzone, 2010; Sunkel, 2011). The aspiration to capitalist economic growth makes these sources highly sought by both Latin American countries and emerging powers.

In the economic interpretation of development, energy and water are vital resources for human life and production, and they cannot be separated from the environment. From this perspective, the strategic 
character of water and energy is linked to their availability for use in productive processes. However, mining is an economic activity that proportionally uses more water and energy and, for that reason, it is more controversial in environmental terms (Norgate and Haque, 2010; Superneau, 2012). Another conceptualization of water and energy comes from an ecological perspective, from which they are not - in a strict sense - economic "resources". They are rather "common goods", and their use has a greater value than simply their exchange value. In this chapter we will consider - from a holistic perspective - water, energy and mining as a complex of interrelated parts ${ }^{6}$; a complex that, in recent years, appears to have been critical to complying (or not) with ecological and environmental principles in Latin America.

Just as energy is required for the consumption of water, so is water for the production of energy (Wu et al., 2013). As both resources are indispensable for mining, it cannot function without the industrial consumption of water and energy (Mudd, 2008). For this reason the mining sector faces the huge challenge of resolving the problem of its high water demand without affecting the availability of water for agriculture and for the urban population, and without increasing pollution (Pizarro, 2012). As for its growing energy demand, the mining sector should seek to satisfy it with maximum efficiency and without increasingly relying on polluting energy sources (e.g. electricity generated by coal, gas or oil) (Zuñiga and Ana, 2009). Along these lines, contentious scenarios lay ahead for every strategic actor interested in defending their legitimacy. In other words, the water-energy-mining complex continues to form a Gordian knot of environmental governance in the mining sector in Latin America and beyond, throughout the socioeconomic structure.

\section{Studying the representations of strategic actors}

We have sought to study the social representations of natural resources and their sustainable consumption among actors and institutions with the capacity for leadership and influence in long-term public policies related to environmental governance. Our main topic of concern is the sustainable consumption of water and energy in the mining sector in Argentina, Chile, Colombia and Ecuador. ${ }^{7}$ In these countries, in distinct stages and with different emphases, metal mining has become one of the pillars of their development policies. Here we focus on the network of actors (Bebbington, 2012) involved in cases of paradigmatic mining projects (some in the exploration phase, most in the operating phase) in these four countries, as shown in Table 6.1. In all countries, 
Table 6.1 Reference cases

\begin{tabular}{|c|c|c|c|c|}
\hline Country & Argentina & Chile & Ecuador & Colombia \\
\hline Projects & $\begin{array}{l}\text { Cerro } \\
\text { Vanguardia }^{1} \\
\text { La Alumbrera }^{2}\end{array}$ & $\begin{array}{l}\text { Mantos } \\
\text { Blancos; } \\
\text { Manto Verde; } \\
\text { Soldado; } \\
\text { Chagres, Los } \\
\text { Bronces }^{3}\end{array}$ & $\begin{array}{l}\text { Fruta del } \\
\text { Norte }^{4} \\
\text { Mirador }^{5}\end{array}$ & La Colosa ${ }^{6}$ \\
\hline Companies & $\begin{array}{l}\text { AngloGold } \\
\text { Ashanti (South } \\
\text { African) and } \\
\text { FormiCruz } \\
\text { (Argentinean) } \\
\text { Xstrata (Swiss), } \\
\text { Goldcorp and } \\
\text { Yamana Gold } \\
\text { (Canadian) }\end{array}$ & $\begin{array}{l}\text { Anglo } \\
\text { American } \\
\text { (British) }\end{array}$ & $\begin{array}{l}\text { Kinross Gold } \\
\text { (Canadian) } \\
\text { Ecuacorriente } \\
\text { (Chinese) }\end{array}$ & $\begin{array}{l}\text { AngloGold } \\
\text { Ashanti (South } \\
\text { African) }\end{array}$ \\
\hline
\end{tabular}

Notes

1. Cerro Vanguardia is a gold and silver mining project in Santa Cruz province.

2. Bajo de la Alumbrera, located in Catamarca, is one of the major metal deposits of copper and gold in the world and is being exploited by means of open pit mining.

3. Anglo American has several, mostly copper, open pit mines in Chile: Los Bronces in the Metropolitana region, Mantos Blancos in the Antofagasta region, El Soldado in the Valparaíso region, Mantoverde in the Atacama region and Collahuasi in the Tarapacá region.

4. The Fruta del Norte gold and silver deposit is a Kinross Gold project that quickly entered into conflict with the Shuar communities. It signed an initial agreement in 2011, but the resistance as well as the company's non-conformity with government regulations has caused Kinross to withdraw from the project.

5. The El Mirador Project in Zamora Chinchipe province, in the Cóndor mountain range, is a copper deposit that is in exploration and its exploitation phase has been approved. It is one of the largest mining projects approved in recent years by the Correa government, not without pressures and conflicts.

6. The La Colosa Project in the Tolima department is the second-largest gold deposit discovered in Colombia. It is a subject of important debate in Colombia because of its social, environmental and economic implications.

socioenvironmental conflicts have been reported. In Colombia and Ecuador, these are primarily related to processes of exploration. In Colombia, the La Colosa project in Tolima has encountered serious resistance from local communities. A similar situation occurred in Ecuador in the Fruta del Norte project, which has since been suspended. In Chile the mining project Doña Inés de Collahuasi, which is partly owned by Anglo American, has received complaints from surrounding communities about water problems, and its current expansion phase is 
controversial. The Alumbrera project in Argentina received the bulk of its complaints when overflows of its mineral pipeline and tailings dam contaminated the Vis-Vis River and the valley's agricultural communities.

The interdisciplinary strategy of this study relies on mixed methods. It is based on a literature review, analysis of primary and secondary sources of an institutional nature, and 65 semistructured interviews with members of so-called strategic actors in the mining sector: CEOs and high executives, senior government officials, political leaders, experts and leaders of NGOs, including community and environmental organizations. The discourse analysis (van Dijk, 2008) was based on semantic techniques. We used a structural discourse analysis, taking into account the overall logic of semantic speech articulation, narrative structures, semantic axes and paradigmatic axes, but focusing on the semiotic square (Greimas, 1966).

\section{Institutional views and actor views}

The theoretical and institutional frameworks that have been developed in regard to the industrial consumption of water and energy in the mining sector come from various sources, primarily from international mining institutions and experts. These expert discourses and institutional discourses of companies, and of public and private institutions, show that the concept of efficiency - as applied to water and energy is the most developed, extensive and referenced. This includes a set of good practices, procedures and technologies that point to an optimization of scarce resources in the diverse phases of the mining lifecycle. The concepts of ecoefficiency (WBCSD, 2013) and natural capitalism (Rábago, Lovins and Feiler, 2001) represent different perspectives on ecological interrelationships between resources. These two concepts have also been applied to the consumption of water and energy in mining, but they are almost inexistent in the discourses of the individual actors from the four case studies.

In regard to the efficient consumption of water and energy, and the incorporation of renewable sources of energy in mining, limited information is generated by corporate discourses. The production of knowledge about the consumption of water and energy in mining is relative to the degree of development of the mining sector in each country, being greater in Chile than in the other countries studied. Institutions such as the International Council on Mining and Metals (ICMM) - the most important corporate regulatory body - have developed a set of 
principles for sustainable mining development (MMSD, 2002; ICMM, 2003). However, only one of ICMM's 46 subprinciples refers to the responsible consumption of water and energy in mining. In the reference cases studied, the relevance of the consumption of water and mining is a theme of a "high level" and experts. It does not, however, seem to be picked up by other social actors. Similarly, references to water and energy consumption in the mining and environmental legislation of the countries studied are scarce (OCMAL, 2012). In the rules and regulations for environmental evaluation and monitoring, these issues are of secondary importance.

In short, the analysis of institutional discourses elucidates the importance of the principles and good practices driven by transnational companies. They emphasize the role of international financial agencies and institutions, such as the International Finance Corporation (IFC, 2012), and principles of environmental evaluation and report, such as the Global Reporting Initiative (GRI, 2011) and BellagioSTAMP (IISD and OECD, 2009).

This study underlines the existence of basic social representations that favour environmental considerations. The interviewed actors in the four countries were asked about the environment, climate change, development models and the relationship of man with nature. They responded in a few typical patterns that show their views on water and energy consumption. Some stress the role of policies of social and environmental responsibility of the mining companies and institutions, reflecting influential discourses at local and international levels. The alternative discourses, which oppose mining projects, resort to interpretational codes derived from a radical reconceptualization of the consumption of water and energy. They focus on their uses, meanings and valuations as associated with the notions of justice, and social and environmental rights.

The statement against which interviewees had to declare their preferences is taken from the mainstream discourses in public policy, saying that "'Sustainable development' in the context of my country's needs would be an economic growth model that mitigates negative environmental and social impacts." ${ }^{8}$ The responses were primarily "strongly agree", which dominated among senior public officials and businessmen, and "disagree", which dominated among environmentalists and (college-educated) experts. We should take note of the emphasis on the idea of economic growth in this proposal, although it is certainly moderated by the idea of mitigating environmental and social impacts. Our results indicate that the concepts associated with growth that 
still dominate in public political and international institutional discourses are assumed by businessmen and experts, while even most politicians and some NGO leaders agree (77\% of all interviewees were in agreement with the statement). Despite a common terminology, social representations of the environment and climate change, technology, the man-nature relationship and development models point to divergent positions. Yet there is a nuanced vision of the future. Asked about whether the future of the country would be clean or polluted, $54 \%$ declared that their country will be cleaner and $46 \%$ declared that it will be more polluted.

\section{Different views and discourse models}

The interviews of strategic actors reveal important discourse structures, which can be classified into four models that express specific views on the consumption of water and energy in mining. However, this specific issue is linked to broader views related to mining and the national development model, which generate distinct perspectives on the environment and environmental policy (Dryzek, 2005). The aim of our analysis was to discover the elementary structures of the meaning in the discourses, followed by a linguistic and extralinguistic (social, political, cultural) interpretation of the discourse. The main elements of the four models are schematically presented in Table 6.2. These models are empirically reconstructed, built semantically through inductive and deductive steps.

\section{Model 1: Indispensable but responsible mining with maximum efficiency}

The first model assumes that the consumption of water and energy should be efficient within the context of responsible mining. Its point of departure is the unconditional affirmation of mining. In regard to water, it seeks to make its consumption efficient and to optimize its reuse:

It seeks to reuse water, to utilize products that are biodegradable so that there is no pollution. ${ }^{9}$

(Argentinean senior executive of a state-private mining company)

The use of water in mining is so serious...that there is already technology to achieve it... (de-pollution). ${ }^{10}$

(Ecuadorian senior executive of a transnational mining company) 


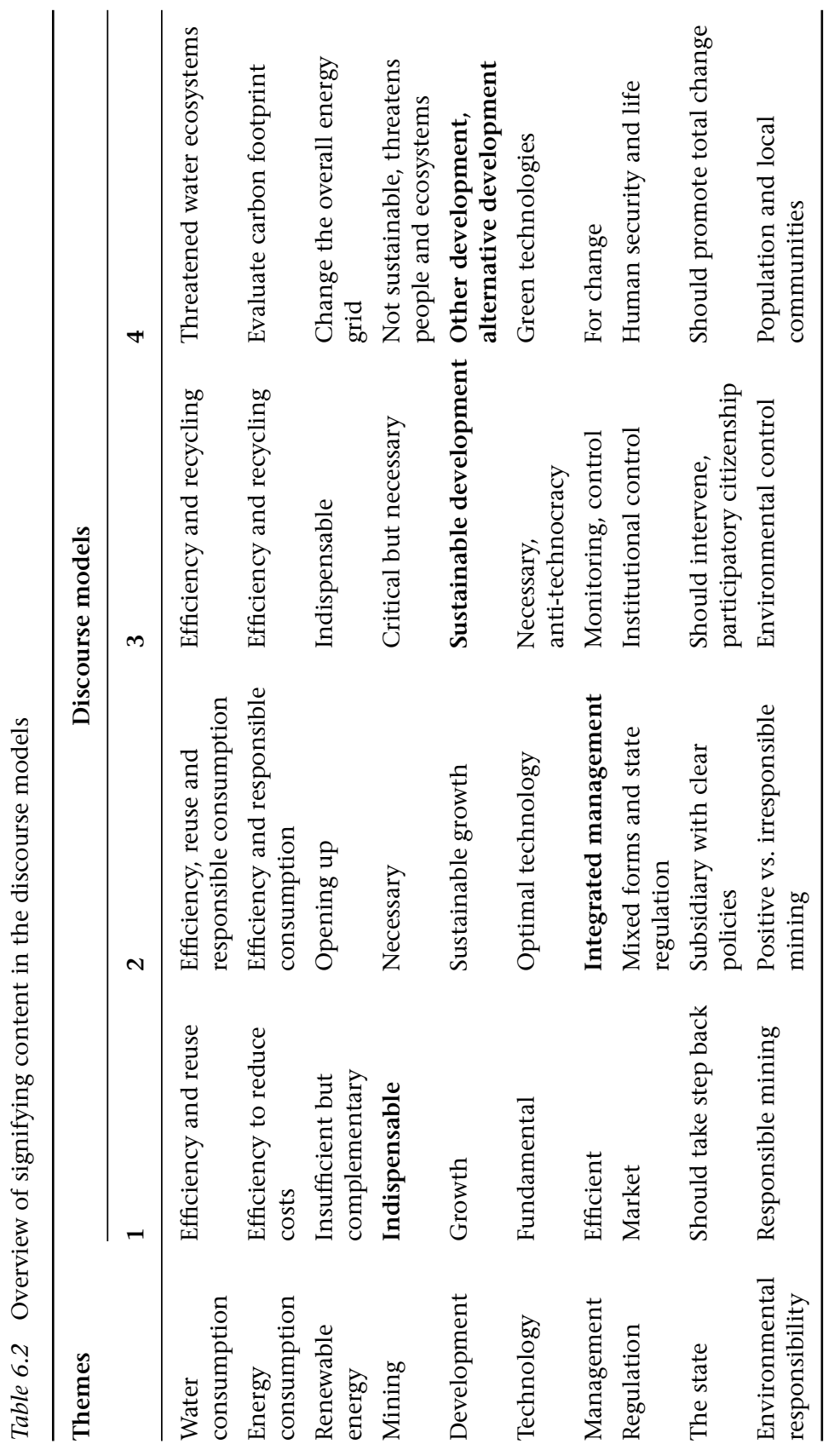


The emphasis is on the fact that water as a resource has a low rate of consumption and is reused through technology. This discourse model seeks forms of efficient water and energy consumption in mining through its rational and balanced use.

I return to the same issue, the consumption of water, the consumption of energy... The goal is to achieve that balance, but if you are a consumer the balance is about the question of how to mitigate consumption. ${ }^{11}$

(Colombian senior executive of a transnational mining company)

The claim is made that the use of water in mining is considerably less than in other activities because of the funnel effect: large quantities of water are manipulated but little is consumed; recycling is very common. This also happens in regions where water resources are abundant (the tropical areas of Ecuador and Colombia, and even in some mountainous areas of Argentina). Water is accumulated in pools and recycled, thus a small amount of water is consumed and its quality is controlled.

In other areas where water is consumed (agriculture), much of the water continues to evaporate. ${ }^{12}$

(Chilean entrepreneur of the National Mining Society)

As for energy resources, this model considers them to be an absolute necessity for mining to function, but recognizes that they are a problem, and even a threat to competitiveness, given their cost. In particular, Chilean and Colombian interviewees problematize the issue of energy while the interviewees from Argentina and Ecuador tend to have a more optimistic perspective. The point of departure is that metal mining is recognized as intensive in terms of energy use, primarily derived from fossil fuels or hydroelectricity. However, this rhetoric downplays the volume of energy consumed.

If mining consumes energy, then the price of energy should take into account the environmental impacts of generating that energy. Therefore, having paid your energy bill, you are fulfilling your role as a responsible consumer. ${ }^{13}$

(Ecuadorian senior executive of a transnational mining company) 
In this discourse model, the energy issue is commodified: it is necessary that the markets operate competitively.

What is stronger in mining and more problematic is electric energy, this issue is very critical ... ${ }^{14}$

(Chilean senior official in the mining industry)

Various projects... have been cancelled because of the high costs of energy ... ${ }^{15}$

(Chilean senior executive of a transnational mining company)

Furthermore, this model fits into a neoliberal conceptual framework that attaches greater relevance to the market than to the state.

The market (should regulate), all of us want the market. I prefer the market...16

(Argentinean senior executive of a transnational mining company)

Assuming that mining requires considerable energy for its processes, facilities and transportation, this discourse model recognizes that most energy comes from fossil fuels. Renewables, they claim, are not the best alternatives because they are expensive and are not processed continuously. Energy from fossil fuels (including electricity generated by gas and coal) is more convenient because of its low price. This discourse model proposes responsible mining that manages to establish a balance between the pursuit of profitability, the environment and social needs: in other words, a legitimate corporate mining activity. It privileges a market environmentalism that prioritizes private initiative but is aware that it should take care of certain environmental and social externalities. It therefore proposes the "rational use of resources", "responsible mining consumption" and "responsible growth".

\section{Model 2: Integrated management, regulation and responsible consumption}

This second discourse model accepts mining as an important development tool. However, it also incorporates reservations about its negative environmental impacts, which can be repaired through proper regulation and institutional norms. 
It is a multiplying activity ... the local population had nothing to do in San Juan, but now there is mining that enhances other activities. ${ }^{17}$

(Argentinean expert and consultant on environmental issues)

Water and energy consumption are represented by a semantic axis of efficiency/inefficiency, where "efficient practices" oppose "inefficient consumption". Resources are scarce and often have high prices, especially energy, which is why efficiency must be promoted.

Being high-tech companies (big mines) ... they should be as energy efficient as possible. ${ }^{18}$

(international expert)

The core idea is "efficiency". Unlike the previous model that emphasized technology as a transforming agent, here the emphasis is placed on integrated and efficient management. Its goal is the responsible consumption of water and energy. This "responsibility" should be assumed by private economic agents, but in case this does not happen the subsidiary state should determine its conditions.

It is the responsibility of the companies as much as of the authorities, how to develop, manage and implement the projects. ${ }^{19}$

(Argentinean expert and environmental consultant)

With respect to water... good mining is technically realized, economically profitable and it ensures the just participation of the Ecuadorian state, a socially responsible mining and mining environmentally managed with strict standards. ${ }^{20}$

(Ecuadorian director of state-owned mining company)

This discourse model favours regulation through "pricing mechanisms", among others, that stipulate mixed policies to enable the proper functioning of the market and forms of state regulation (environmental evaluation, laws and norms, effective fiscalization). The model proposes the establishment of clear energy policies that frame energy consumption in mining. This model seeks to "regulate" the energy grid with "rules" that are associated with "clear environmental policies". These "clear policies" must be given within the framework of a subsidiary state. The state should then intervene to adequately regulate and make the market function conveniently by establishing conditions for private investment in the form of laws, regulations and institutions. 
The incentives are well placed when the decision maker has internalized - to the greatest extent possible - all of the potential (environmental) costs that energy use represents. ${ }^{21}$

(Chilean senior official and ex-minister of the state)

Regulation requires planning, evaluation and control of mining activity. From this perspective communities have to be prevented from deepening their opposition to mining projects and impeding the functioning of institutions and regulations. A clear policy that involves "integrated regulation" is fundamental for "legal certainty" to exist and to incentivize mining investment. The responsible consumption of water and energy in mining must point towards "sustainable growth".

In this discourse model there are some views and positions that are critical of the rationale of those who want to grow at any cost. It seeks to promote responsible growth at a responsible growth rate. For instance, an international expert recognizes that this is not necessarily a consistent practice of big mines, where emphasis is placed on the general discourse about CSR. This is not necessarily linked to a vision of integrated, efficient and responsible management of water and energy. In summary, this model generates a clear sense of the consumption of water and energy in mining with explicit central concepts, such as efficiency, recycling, integrated management and responsible consumption. Its second focus is on establishing the institutions and conditions that allow for better regulation and for the establishment of certain regulations that guarantee private investment and frame the responsible consumption of water and energy in mining.

\section{Model 3: Sustainable development and institutional control}

This model makes strong statements about water and energy consumption in mining, focusing on the more political concept of sustainable development. It assumes that mining has negative environmental and health effects. This gives rise to various degrees of criticism of mining, but it agrees that - under certain conditions - mining is a necessary activity.

I think that (mining) is worth the effort because the activity, if well developed, can be done with a relatively low level of environmental impact. I am talking about a mining at a scale... (that is) more human...22 
In this discourse, mining is problematic due to contamination from heavy metals. This is the origin of the need for efficiency and recycling in water and energy consumption, and - given the environmental crisis - the need for environmental control that guarantees sustainable mining.

In the case of water ... it must be addressed through strict control over available resources. ${ }^{23}$

(Chilean politician, representative of the center-left)

... it should be, as I say, with the least environmental impact. ${ }^{24}$

(Ecuadorian politician, progressive Congressman)

However, this control and monitoring supposes the existence of a state that clearly intervenes and regulates the market, and a democratic citizenship that participates, monitors and combats corruption. As for energy, the fundamental semantic axis resides in the contrast of "carbon energy" with "renewable energy".

And in Chile ... the energy grid is overly carbonized..$^{25}$

(Chilean politician, representative of the left)

Our indigenous discourse has always been to defend the rights of nature... For that reason the president has decided to change the energy grid, for example from thermoelectric to hydroelectric energy .... ${ }^{26}$

(Ecuadorian indigenous leader, progressive representative)

In summary, this model is based on a political proposal of sustainable development, which criticizes the environmental impact of mining but includes mining as a factor of development. It subjects mining to controls, rules and regulations, and seeks to encourage the sustainable consumption of water and energy by promoting efficiency, recycling and a transition to renewable energy, including this transition within the mining sector itself. It proposes sustainable development with the clear intervention of the state in order to guarantee a market with clear and competitive rules. It intends to combat monopoly and corruption, and to stimulate citizen participation. In short, water and energy consumption is perceived as a political problem and not only one of technical management. 


\section{Model 4: Alternative development for the protection of common goods}

This discourse model departs from a critique of the environmental consequences of mining. It represents "immense risks", "environmental destruction", "water pollution", "wars" and even "death".

Mining is non-viable or incompatible with the life of many human beings ... ${ }^{27}$

(Chilean environmental NGO leader)

No mining is clean - it incites serious problems; the pollution is incredible. ${ }^{28}$

(Ecuadorian senior official, ex-Minister of State)

The main semantic axis that stimulates the discourse is "life" versus "death"; mining has become "incompatible with life". Human life and nature would be in danger: peasants, indigenous and communities as well as ecosystems would be threatened.

In this discourse, the "rights of nature" are inextricably linked to the human rights of the affected populations, the communities and the indigenous people. Natural resources in this discursive view are meant for common use related to the rights of the community (residents, indigenous, etc.) and of society (the state). They are semantically disjointed from exchange values (the mining market), and should be neither commodified nor privatized. In general, the texts speak of the water-energy-mining complex as a whole, in sociotechnical and in sociopolitical terms. According to this view, as mineral reserves decrease, the intensive consumption of water and energy further increases. While the global mineral demand increases, the pressure for more intensive forms of production (in terms of capital employed) grows, along with policies to raise productive efficiency and efficacy in order to achieve maximum "competitiveness" and profitability in the global metal mining market.

In general, this discourse model goes beyond the references to specific issues such as water management and energy efficiency in terms of industrial mining consumption. Instead, concepts of greater abstraction, such as "ecosystems" and "carrying capacity", are used. The interviewees who fit into this model claim that both mining companies and the authorities have agreed to water consumption that is greater than nature's "carrying capacity", and that "overconsumption" of natural resources is fostered by the "extractivist model". 
I insist, we should put the little resources that we have left (water and energy) towards alternatives for the future, not towards satisfying the needs of such a small percentage of the population ... ${ }^{29}$

(Argentinean leader of an environmentalist assembly, when referring to gold mining)

As for consumption, the discourse associates it with the "extractivist model" and opposes it to "another development" that is "nonconsumerist". The latter is a mode of production that relies on mining "for the bare necessities" and that develops from values such as "solidarity" instead of "competitiveness".

We do not call them "natural resources", but rather "common goods". ${ }^{30}$

(Argentinean environmental leader)

With regard to energy consumption, this discourse model clearly favours the use of renewable energy, inclined towards non-conventional renewables but especially insisting on thinking about the global energy system in a different way.

We are the country of the sun, the country of water, here we have potential and we have possibilities to generate a type of energy other than oil. ${ }^{31}$

(Ecuadorian leader of an environmental NGO)

Compared with mining megaprojects, local projects with renewable energy at a "human scale" are favoured in the context of another (postoil) energy system: hydroelectric energy and/or solar energy projects that can be developed along with communities and local governments. In that way, they could overcome the megaprojects' overconsumption of energy and water. There is talk of generating conditions so that the new mining projects would have a reduced "ecological footprint", "water footprint" and "carbon footprint". Perceptions of the intergenerational and long-term environmental impacts are present in this discourse model. It has strong Utopian connotations, an ideal that is inspired by values such as the "good life" and ecodevelopment from empowered local social actors.

In summary, this discourse model formulates social representations of water and energy consumption in the mining sector from a codification of meaning that proposes a systemic change with communities, 
especially those of the indigenous, as main points of reference. It is a critical look at the current development model and public policies, including those of the "progressive" governments. It advocates a change in capitalist modes of production - encouraging citizen participation, and decentralized and self-managed forms of production - with a clear preference for non-conventional renewable energy. In general, the alternatives to water and energy consumption in the mining sector are subordinate to issues of a greater magnitude. Mining should be rejected when it affects regions that are rich in biodiversity, water resources and ecosystems. This includes the risk of utilizing excessive amounts of water and energy.

\section{Conclusions: Governance of sustainable water and energy consumption in mining?}

The interviews reveal that there is a consensus of "environmentalist" language with regard to common issues. Corporate environmental responsibility, protection of and care for the environment, concern about water and energy consumption, and an orientation towards sustainable development are mentioned as necessary by all interviewees. ${ }^{32}$ But beyond the discursive rhetoric, deep code analysis reveals very different and even contradictory concepts about the following subjects: the environment, the responsibility of strategic actors for resources such as water and energy, the role of the government, and the waterenergy-mining complex, which ultimately reflects different worldviews and epistemes about the relationship of man with nature.

In general, we observe that these different discourses are set forth and projected at different scales (transnational, national and local) and levels (business, government and politics, and civil society), and that there is little room for dialogue. They maintain positions in the social structure of elites: the first model is set forth mostly by CEO and high executives, and some senior government officials; the second model is affirmed by experts and also by senior officials; the third model is set forth by politicians and experts (but is slightly more important among politicians); and the fourth model pertains to environmental leaders and some politicians.

The consumption of water and energy in mining, seen in the light of the analysed discourses, is not an exclusively technical subject. The worldviews, linked to the social positions and interests of stakeholders, frame patterns of action and have an impact on the way in which the sustainable consumption of natural resources is represented. But 
they go beyond that because of the obvious practical consequences that they have and will have in social and political aspects. The first two discourse models have a technical bias (hard technologies and management technologies); the third and fourth discourse models have ideological-political biases, the last being traversed by ecological worldviews.

From the perspective of environmental governance, the positions behind the models point at disagreement. They will be a great source of conflict to the extent that some defend the thesis of economic growth, taking ecological factors into account only as secondary externalities (positions found in the first model). Others take an alternative stance, proposing an ecological perspective that focuses on avoiding economic growth and overconsumption in the neo-extractivist Third World (positions found in the fourth model).

The analysed discourses, with few exceptions, do not take long-term environmental risks into account. The central grid of this discursive logic is the capacity to control and intervene in water and energy consumption in mining, through technocratic (first model), normative and institutional (models two and three), or political-environmental (models three and four) means. The abstraction of the accumulative and latent effects of the long-term environmental impacts of the abovementioned consumption is proof that the autonomized effects of sociotechnical processes as a result of the increased extractive economy in the region are unknown.

Our study of discourses confirms that most of the stakeholders who are more likely to defend the expanded reproduction of the waterenergy-mining complex - as the basis of the socioeconomic development of the region - do not take responsibility for the international and global implications of local environmental behaviour. The majority of these actors do not think in terms of a long-term global horizon. Consequently, the problems of climate change and the decisions that they implicate in terms of energy and water policy are considered without taking into account the reflexivity of local social processes in overall environmental risks. The structural positions of these stakeholders in developing countries, in the periphery of the world system, thus condition discourses with respect to these global implications.

In this chapter we first presented the problem of water and energy consumption in the mining sector, situated within the water-energymining complex. We sought to clarify linear, sectorial and reductionist perspectives and to approach a perspective that integrates synergies among discourses, rules, technologies, institutions and interpretations 
both diverse and contentious elements of environmental governance. The majority of the discourses ignore these interrelationships. Therefore the deeper significance of the overconsumption of resources, from which future scarcity of water and energy as well as consequences of climate change are expected, does not seem to be present in the majority of the analysed discourses.

In view of the transition towards more sustainable patterns, it is important to note that the first and second discourse models are associated explicitly with a confidence in technological innovation. The third and fourth model, on the other hand, introduce a more political and ecological logic in their vision of resource consumption in mining. The considerations about the intensity of use of water and energy resources in mining, as well as the technological structure with which they are associated, should be considered simultaneously as integrated systems that assume social, political and ecological connotations. The analysis of the processes of technological innovation linked to the shift towards sustainable consumption of water and energy in mining cannot neglect the associated social and political variables. In addition, this study of social representations of water and energy consumption of strategic South American actors demonstrates the recent increase in environmental consciousness.

In general, we observe that there is a struggle for legitimacy going on between conflicting discourses. The contradictory positions are opposite poles in a space of dialogue that should be promoted by a public policy that seeks environmental sustainability and resource governance. The recognition of the conflict of interests and views, and the discourse models with divergent positions - whose possibility for dialogue is still an open question - clearly demonstrate that there is a series of challenges ahead for environmental governance and for achieving sustainability in the extractive industries.

\section{Notes}

1. See the Environmental Justice Atlas of the EJOLT Project at http://ejatlas.org/

2. See http://www.anglogoldashanti.com/en/Pages/default.aspx

3. In accordance with the Center for Copper and Mining Studies (Cesco), with headquarters in Santiago, Latin America will become the most important region in the world for attracting investments for mining development, with a record number of US\$327 billion between 2011 and 2020. See the Metals Economic Group (2013).

4. We understand social representations in accordance with Höijer (2011) and Moscovici (1981). 
5. For more information on sustainable consumption, see Parker et al. (2012).

6. This refers to the mining-energy complex (Baker, 2012; Sharife and Bond, 2012). We have expanded this to the concept of the water-energy-mining complex from the sociotechnical and sociopolitical perspective. In South America, as is also shown in the case of South Africa (Sharife and Bond, 2012), it is furthermore a structure of power through which the elites have historically appropriated those resources.

7. For information about the mining sector in Argentina, see Svampa and Antonelli (2009); Walter and Martinez-Alier (2010); Baigorrotegui, Parker and Estenssoro (2014); in Chile, see Newbold (2006); in Colombia, see Garay (2013); in Ecuador, see Bustamante and Rommel (2010); van Teijlingen (2012).

8. "El 'desarrollo sustentable' en el contexto de las necesidades de mi país sería un modelo de crecimiento económico con medidas de mitigación de los impactos ambientales y sociales negativos".

9. "se busca reutilizar el agua, se busca utilizar productos que sean biodegradables de manera tal que no exista contaminación".

10. "el uso del agua en la minería no es tan grave... ya existe la tecnología para lograrlo... (la descontaminación)".

11. "Vuelvo a lo mismo, el consumo de agua, el consumo de energía ... El objetivo es lograr ese equilibrio, donde si usted consume el equilibrio es ¿cómo mitiga ese consumo?".

12. "en las otras áreas (agricultura) que consumen agua, se sigue evaporando mucha agua".

13. "Si la minería consume energía, pues en el precio de la energía debe estar considerado los impactos ambientales de generar esa energía. Por lo tanto, habiendo pagado su factura de energía, está cumpliendo con su rol de consumidor responsable."

14. "lo que es más fuerte en la minería y es más problemático, es la energía eléctrica, ese tema es bastante crítico...".

15. "varios proyectos... se han estado cancelando por los altos costos de la energía...".

16. "El mercado (debe regular), todos queremos el mercado. Prefiero al mercado...".

17. "Es una actividad multiplicadora ... el sanjuanino no tenía qué hacer en San Juan, en cambio, hay desarrollo minero que potencia otras actividades."

18. "siendo que son empresas de alta tecnología (grandes mineras)... deberían estar siendo lo más eficiente energéticamente posible".

19. "es responsabilidad tanto de las empresas como de las autoridades, cómo desarrollar, cómo manejar, cómo hacer el implemento de los proyectos".

20. "en lo que concierne al agua... una buena minería que sea técnicamente realizada, económicamente rentable y que garantice una justa participación del Estado Ecuatoriano, una minería socialmente responsable y una minería ambientalmente manejada con rígidos estándares".

21. "Los incentivos están bien puestos cuando el que toma la decisión, tiene lo más internalizado posible todos los costos (ambientales) que representa el que use energía." 
22. "Creo que vale la pena (la minería) porque la actividad, bien desarrollada, puede hacerse con un nivel de impacto ambiental relativamente bajo, o sea, hablo de una minería a escala ... más humana...".

23. "En el caso del agua... tiene que ser abordada a través de un control estricto y eso con los recursos disponibles".

24. "debe ser como digo con el menor impacto ambiental...".

25. "Y en Chile ... la matriz energética está demasiado carbonizada".

26. "Nuestro discurso indígena siempre ha sido defender los derechos de la naturaleza... Por eso también el presidente ha decidido cambiar la matriz energética, por ejemplo de energía termoeléctrica a energía hidroeléctrica...".

27. "está siendo inviable o incompatible la vida de mucha gente con la minería...".

28. "Ninguna minería es limpia ... ocasiona gravísimos problemas, las contaminaciones son increíbles."

29. "Insisto, los pocos recursos que nos quedan (agua y energía) debemos emplearlos en alternativas para un futuro, no en satisfacer las necesidades de un porcentaje tan bajo de la población..."

30. "nosotros no les llamamos 'recursos naturales', sino 'bienes comunes' ".

31. "Somos el país del sol, el país del agua, aquí tenemos posibilidades y tenemos posibilidades de generar otro tipo de energías que en términos de petróleo."

32. This subject is nothing new. Beck observed - in his analysis of the subjectivity of politics since the 1980s, and then accelerated since the collapse of the Berlin Wall - the environmental concern for a threatened world that haunted Europe. Beck said that this concern, which "united conservatives with socialists ... is only appearance, programmatic opportunism, perhaps occasionally an authentic reassessment" (Beck et al., 2001: 34-35).

\section{References}

Baigorrotegui, G., Parker, C. and Estenssoro, F. (2014) "Visiones sobre los Tránsitos Socio-Técnicos hacia Patrones de Consumo Sustentable en Agua y Energía en la Minería Sudamericana. Dos Controversias Argentinas", Sociologías 16(37): 72-111.

Baker, L. (2012) "Power Shifts In South Africa's Minerals-Energy Complex: From Coal Crunch To Wind Rush?", Paper for Political Economy and the Outlook for Capitalism, Congress, 5-7 July 2012, Paris.

Bebbington, A.J. (ed.) (2012) Social Conflict, Economic Development and Extractive Industry: Evidence from South America (London: Routledge).

Beck, U., Giddens, A. and Lash, S. (2001) Modernización Reflexiva Política, Tradición y Estética en el Orden Social Moderno (Madrid: Alianza).

Bruzzone, E. (2010) Las Guerras del Agua. América del Sur en la Mira de las Grandes Potencias (Buenos Aires: Capital Intelectual).

Bustamante, T. and Rommel, L. (eds) (2010) El Dorado o la Caja de Pandora. Matices para Pensar la Minería en Ecuador (Quito: Flacso-Sede Ecuador).

Dijk, T. van (2008) El Discurso como Estructura y Proceso (Barcelona: Gedisa).

Dryzek, J.S. (2005) The Politics of the Earth, Environmental Discourses (New York: Oxford University Press). 
Garay Salamanca, J.L. (2013) Minería en Colombia. Fundamentos para Superar el Modelo Extractivista (Bogotá: Contraloría General de la República).

Greimas, A.J. (1966) Sémantique Structurale (Paris: Larousse).

GRI (2011) "RG, Sustainability Reporting Guidelines 2000-2006", version 3.0, www.globalreporting.org, date accessed 2 February 2015.

Hajer, M. and Versteeg, W. (2005) "A Decade of Discourse Analysis of Environmental Politics: Achievements, Challenges, Perspectives", Journal of Environmental Policy and Planning 7(3): 175-184.

Höijer, B. (2011) "Social Representations Theory, a New Theory for Media Research", Nordicom Review 32(2): 3-16.

ICMM (2003) Marco Conceptual sobre Desarrollo Sustentable del ICMM. Principios del ICMM (Londres: Consejo Internacional de Minería y Metales).

IFC (2012) Performance Standards on Environmental and Social Sustainability (Washington, DC).

IISD and OECD (2009) BellagioSTAMP: Sustainability Assessment and Measurement Principles (Winnipeg: International Institute for Sustainable Development and Organisation for Economic Co-operation and Development).

Metals Economics Group (2013) Worldwide Explorations Trends 2013, http://www.metalseconomics.com/sites/default/files/uploads/PDFs/meg wetbrochure2013.pdf, date accessed 6 January 2015.

MMSD (2002) Breaking New Ground: Mining, Minerals and Sustainable Development (Londres: IIED).

Moscovici, S. (1981) "On Social Representation", in J.P. Forgas (ed.), Social Cognition. Perspectives in Everyday Life (London: Academic Press).

Mudd, G.M. (2008) "Sustainability Reporting and Water Resources: A Preliminary Assessment of Embodied Water and Sustainable Mining", Mine Water and the Environment 27(3): 136-144.

Newbold, J. (2006) “Chile's Environmental Momentum: ISO 14001 and the LargeScale Mining Industry - Case Studies from the State and Private Sector", Journal of Cleaner Production 14(3-4): 248-261.

Norgate, T. and Haque, N (2010) "Energy and Greenhouse Gas Impacts of Mining and Mineral Processing Operations", Journal of Cleaner Production 18(3): 266-274.

OCMAL (2012) Legislación Minera en el Derecho Comparado: los Casos de Chile, Ecuador, Perú, Guatemala y el Salvador (Observatorio Latinoamericano de Conflictos Mineros, FEDEPAZ).

Parker, C., Baigorrotegui, G., Estenssoro, F., Muñoz, J. and Bull, B. (2012) "Strategic Actors and Sustainable Consumption in Latin America and the Caribbean (LAC). Case Studies in the Mining Sector", ENGOV Project, Analytical Framework Report, www.engov.eu

Pizarro, N. (2012) "Agua Recurso Estratégico en Minería", C. CEO SCM Minera Lumina Copper Chile, Caserones, Santiago. Presentación PP. en EXPOMIN, Santiago, marzo 2012. www.expomin.cl/marketing/pdf/.../presentacion_ nelson_pizarro_c.pdf, date accessed 15 December 2014.

PNUMA, SEMARNAT (2006) El Cambio Climático en América Latina y el Caribe (México, DF: Secretaría de Medio Ambiente y Recursos Naturales y PNUMA Programa de las Naciones Unidas para el Medio Ambiente).

Rábago, K.R., Lovins, A.B. and Feiler, T.E. (2001) "Energy and Sustainable Development in the Mining and Minerals Industries", Mining, Minerals and 
Sustainable Development (MMSD) $\mathrm{N}^{\circ} 41$ (London: Internacional Institute for Environment and Development (IIED), World Business Council for Sustainable Development, (WBCSD)), http://pubs.iied.org/G00540.html

Sharife, K. and Bond, P. (2012) "South Africa's Minerals Energy Complex", in H. Healy, J. Martinez-Alier, L. Temper, M. Walter and J. Gerber (eds), Ecological Economics from the Ground Up (London: Routledge), 163-188.

Sunkel, O. (2011) "América Latina entre el Cuidado y la Dependencia de sus Recursos Naturales", in A. Cubillos and F. Estenssoro (eds), Energía y Medio Ambiente. Una Ecuación Difícil para América Latina (Santiago: Idea, Instituto Igualdad).

Superneau, L. (2012) "Problemas en las Alturas: Conflictos por el Agua en las Industrias Mineras de Chile y Perú", Business News Americas, Mining Intelligence Series, http://member.bnamericas.com/webstore/es/intelligence-series/ high-and-dry-water-issues-in-chile-and-perus-mining-industries, date accessed 3 December 2014.

Svampa, M. and Antonelli, M (eds) (2009) Minería Transnacional. Narrativas del Desarrollo y Resistencias Sociales (Buenos Aires: Editorial Biblos).

Teijlingen, Karolien van (2012) Negotiating Values and Development at the Mining Frontier: Private, Public and Civil Society Interactions over El Mirador Mine in South East Ecuador, Master Thesis (Amsterdam: University of Amsterdam).

Walter, M. and Martinez-Alier, J. (2010) "How To Be Heard When Nobody Wants to Listen. Community Action Against Mining in Argentina", Canadian Journal of Development Studies 30(1-2): 281-303.

WBCSD (2013) "Eco-Efficiency Learning Module", World Business Council for Sustainable Development, http://www.wbcsd.org/Pages/EDocument/ EDocumentDetails.aspx?ID=13593\&NoSearchContextKey=true, date accessed 29 March 2013.

Whitmore, A. (2006) "The Emperor's New Clothes: Sustainable Mining?", Journal of Cleaner Production 14(3-4): 309-314.

Wu, M., Mintz, M., Wang, M., Arora, S. and Peng, J.K. (2013) "Water Is Key for Sustainability for Energy Production", Argonne Nacional Laboratory, US Department of Energy, Chicago. http://www.transportation.anl.gov/pdfs/AF/620.PDF, date accessed 29 March 2014.

Zúñiga S. and Ana I. (2009) "Consumo de Energía y Emisiones de Gases de Efecto Invernadero de la Minería del Cobre de Chile", Departamento de Estudios y Políticas Públicas, Comisión Chilena del Cobre ponencia en Seminario Vulnerabilidad, Adaptación y Mitigación para el Cambio Climático en Chile, Santiago, 24 de septiembre de 2009.

Except where otherwise noted, this work is licensed under a Creative Commons Attribution 3.0 Unported License. To view a copy of this license, visit http://creativecommons.org/licenses/by/3.0/ 